\title{
The Design and Performance of a PEFC at a Temperature Below Freezing*
}

\author{
Yukio HISHINUMA**, Takemi CHIKAHISA**, \\ Fumio KAGAMI** and Tomohiro OGAWA**
}

\begin{abstract}
At temperatures below freezing, air humidity becomes lower and produced water at the cathode freezes on the surface of catalyst, and it is difficult to start a PEFC (Polymer Electrolyte Fuel Cell) at a cold district. The object of the work is to study the performance of the fuel cell below the freezing point by experiments and simulation. To investigate the characteristics of the starting of a temperature below freezing the performance of a single cell was measured at temperatures from -3 to $-25^{\circ} \mathrm{C}$ and pressures from 1 to $2 \mathrm{~atm}$. The results of the experiments and simulation indicate that the performance of a PEFC decreases at higher current densities and pressures, and lower cell temperatures because of ice more produced on the reactive area of the cathode. To maintain the cell performance below freezing point, it is effective to adjust the current densities and gas flow rate to balance the produced and removed water. However at $-5^{\circ} \mathrm{C}$, heat generated in the fuel cell is effective to warm the cell and make self-starting possible. These results shows that it is necessary to heat the cell with an additional heat source in order to start the fuel cell below $-5^{\circ} \mathrm{C}$.
\end{abstract}

Key Words: Fuel Cell, Polymer Electrolyte, Performance, Simulation, Cold-Start, Freezing

\section{Introduction}

The PEFC consists mainly of a proton exchange membrane with hydrogen and oxygen porous gas diffusion electrodes on each side, which must be maintained to be wet to ensure good performance. However at temperatures below freezing, water freezes on the electrode and air humidity becomes lower, and it is difficult to maintain the power output. The reactions taking place in a fuel cell are as follows:

$$
\begin{aligned}
& \text { Anode }: \mathrm{H}_{2} \rightarrow 2 \mathrm{H}^{+}+2 \mathrm{e}^{-} \\
& \text {Cathode }: 2 \mathrm{H}^{+}+1 / 2 \mathrm{O}_{2}+2 \mathrm{e}^{-} \rightarrow \mathrm{H}_{2} \mathrm{O} \\
& \text { Total }: \mathrm{H}_{2}+1 / 2 \mathrm{O}_{2} \rightarrow \mathrm{H}_{2} \mathrm{O}
\end{aligned}
$$

The fuel oxidation takes place at the anode and the oxidant reduction at the cathode. As a result, water is produced at the cathode side, and at temperatures below freezing, the fuel cell performance is affected by the freezing of the produced water. Yoshikawa et al. ${ }^{(1)}$ showed that

\footnotetext{
* Received 30th July, 2003 (No. 03-4182)

** Department of Mechanical Science, Hokkaido University, N13, W8, Sapporo, Hokkaido 060-8628, Japan.

E-mail: hishiyujp@ybb.ne.jp
}

it was possible to operate fuel cells at low current densities, and that the drop in fuel cell voltage was due to a reduced reactive area because of freezing of the produced water. Takagi et al. ${ }^{(4)}$ and Kagami et al. ${ }^{(6)}$ showed that it was possible to operate at higher current densities by adjusting the current density and gas flow rate to balance the amount of the produced water and the water that the cathode gas carries away. The object of the work here is to study the freezing behavior of the produced water at the cathode and to establish the operating temperature that makes self-starting below the freezing point possible even at a pressurized condition.

\section{Nomenclature}

$A_{v}:$ catalyst surface area per unit volume $\left[\mathrm{cm}^{2} / \mathrm{cm}^{3}\right]$

$C:$ concentration $\left[\mathrm{mol} / \mathrm{cm}^{3}\right]$

$D:$ diffusion coefficient $\left[\mathrm{cm}^{2} / \mathrm{s}\right]$

$F:$ Faraday constant $[\mathrm{A} \cdot \mathrm{s} / \mathrm{mol}]$

$i_{0}^{+}$: exchange current density $\left[\mathrm{A} / \mathrm{cm}^{2}\right]$

$I_{y}$ : current density distribution for $y$ direction $\left[\mathrm{A} / \mathrm{cm}^{2}\right]$

$J:$ current density $\left[\mathrm{A} / \mathrm{cm}^{2}\right]$

$k$ : reactive area covered with frozen water per water molecule $\left[\mathrm{cm}^{2} / \mathrm{mol}\right]$ 


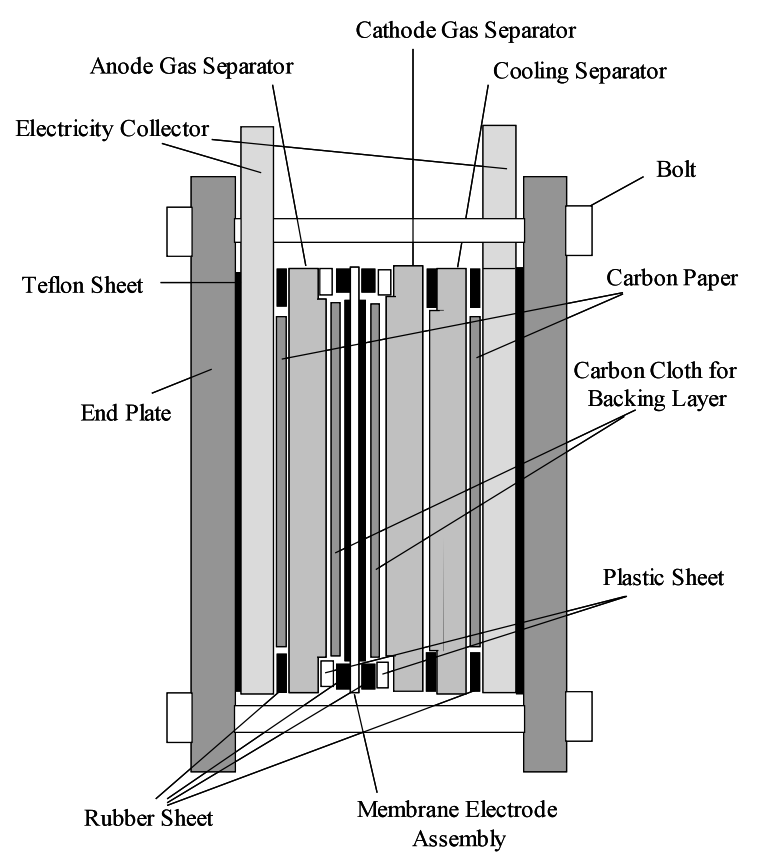

Fig. 1 Cross section of the PEFC

$N_{i}$ : molar flux of species $i\left[\mathrm{~mol} / \mathrm{cm}^{2} \cdot \mathrm{s}\right]$

$n_{d}$ : electro-osmotic drag coefficient (number of water molecules carried per proton)

$R$ : gas constant $[\mathrm{J} / \mathrm{mol} \cdot \mathrm{K}]$

$T_{s}$ : temperature of fuel cell $[\mathrm{K}]$

$W_{c f}:$ frozen water $\left[\mathrm{mol} / \mathrm{cm}^{3}\right]$

\section{Greek}

$\alpha$ : net water flux per proton flux

$\alpha_{k}$ : anodic or cathodic transfer coefficient for $\mathrm{O}_{2}$ electrode

$\eta$ : cathode overpotential [V]

$\sigma_{\text {cat }}:$ catalyst layer conductivity $[1 / \Omega \cdot \mathrm{cm}]$

\section{Experiment}

Figure 1 is the cross section of the fuel cell tested. A fuel cell with a $104 \mathrm{~cm}^{2}$ effective area of membrane and electrode assembly was used in this work. The M \& E assembly, PRIMEA5561, was purchased from JAPAN GORE-TEX Inc., and incorporated in the single cell test fixture. The single cell is composed of the stainless steel end plates, Teflon sheets for electric insulation, current collector copper plates, graphite plates with ribbed channels for the distribution of reactant gases, graphite fiber cloth to protect the electrodes and the whole of the M \& E assembly. Figure 2 shows an outline of the experimental apparatus; the single cell was installed in this test facility.

In the experiments, hydrogen was used as fuel and mixed gas $\left(\mathrm{N}_{2} 79 \%, \mathrm{O}_{2} 21 \%\right)$ as oxidizer. Dry gas was supplied through mass flow controllers, and the current was controlled with an electronic load and a constant voltage source connected in series. The fuel cell was operated in a refrigerator to maintain the test temperatures. The gas

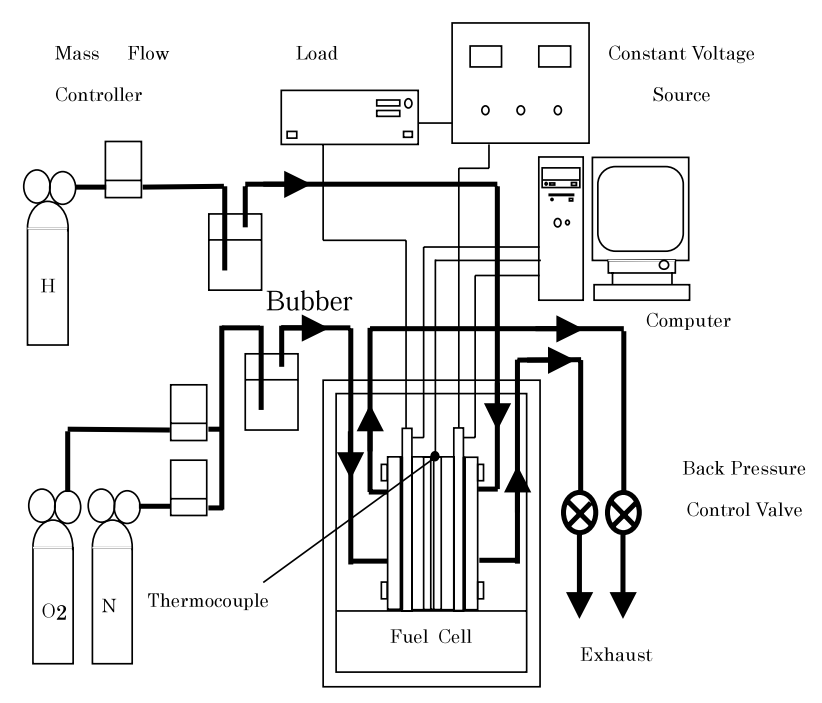

Fig. 2 Experimental apparatus

flow rate was changed with the current to maintain a constant gas utilization at temperatures of 40 to $-25^{\circ} \mathrm{C}$. The cell potential vs. current density was measured. The control valve set up at the exhaust, controlled pressures of the test cell from 1 to $2 \mathrm{~atm}$.

\section{Simulation Model}

This simulation model is an unsteady-state, threedimensional heat, and mass-transfer model of a PEFC simulating the cell performance at temperatures below freezing. The model ${ }^{(2),(3),(5),(6)}$, developed previously, was further developed to consider freezing of the produced water. Figure 3 is a schematic illustration of a PEFC. The model accounts for the mass transfer of water and gaseous reactants across the membrane along the flow channels. Figure 4 shows the three dimensional model of the heat transfer from the solid phase to the gases considering heat conduction, convection, and enthalpy transfer in the $x, y$, and $z$ directions. Water molecules move from the anode to the cathode, due to electro-osmosis, resulting in flooding on the cathode and additional water is produced at the cathode by the reaction, $2 \mathrm{H}^{+}+1 / 2 \mathrm{O}_{2}+2 \mathrm{e}^{-} \rightarrow \mathrm{H}_{2} \mathrm{O}$.

The equations for the water transport are as follows:

$$
\begin{aligned}
& N_{\mathrm{H}_{2}}=\frac{J}{2 F} \quad N_{\mathrm{O}_{2}}=\frac{J}{4 F} \quad N_{\mathrm{N}_{2}}=0 \quad N_{\mathrm{CO}_{2}}=0 \\
& N_{\text {w.a }}=\frac{\alpha J}{F}=W_{a} \quad N_{\text {w.c }}=\frac{(1+2 \alpha) J}{2 F}=W_{c}
\end{aligned}
$$

The water flux at the anode is calculated as follows: here $n_{d}$ is the electro-osmotic coefficient and $D_{w}$ is the diffusion coefficient of water in the membrane.

$$
N_{w . a}=n_{d} \frac{J}{F}-D_{w} \frac{d c_{w}}{d y}=W_{\mathrm{H}_{2} \mathrm{O}}-W_{d}
$$

The electro-osmotic coefficient depends on the water content in the membrane, which in turn depends on the activity of water in the gas phase. The two terms on the right 


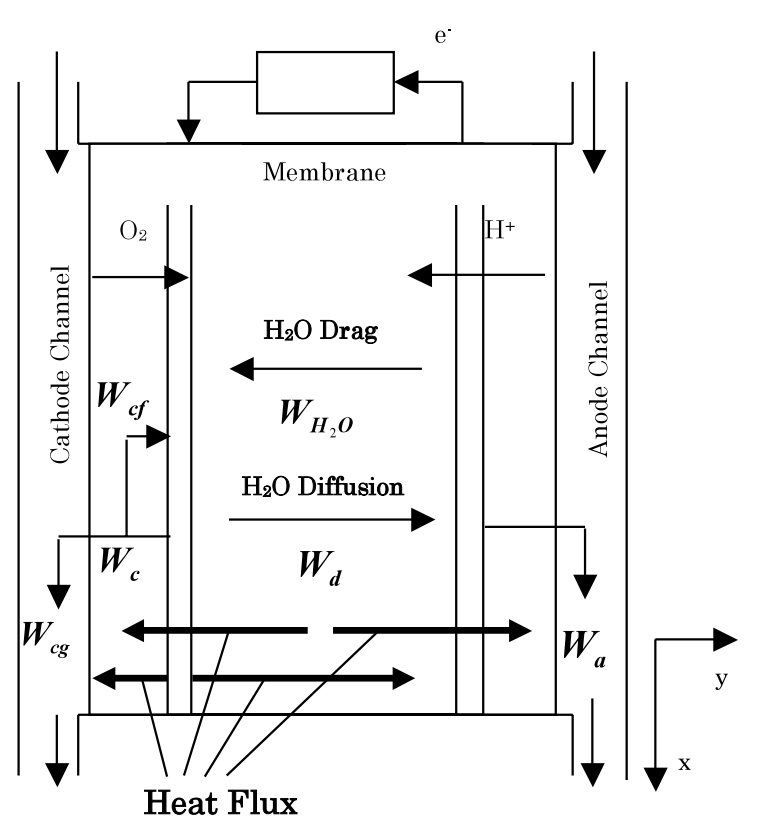

Fig. 3 Model for the simulation of the fuel cell operation

side of the Eq. (5) express the migration of water from the anode to the cathode, $W_{\mathrm{H}_{2} \mathrm{O}}$, and the back diffusion from the cathode to the anode, $W_{d}$. The method to calculate $n_{d}$, and $D_{w}$ is shown in more detail in the Refs. (2) and (5).

As the water concentration in the gases is very low at temperatures below freezing, dry-gases were used as the anode and cathode gases in this experiment. As a result some produced water is carried away with the reactant gases that have been saturated with steam. The quantity of water at the anode and cathode sides were calculated in one dimension by the simulation model, and is shown in Fig. 5 assuming no freezing at $-10^{\circ} \mathrm{C}$. The water is produced at both the anode and cathode and the amount of cathode water is about ten times the amount of anode water. Considering this result, the following assumptions were made:

(1) As much less water is produced at the anode than at the cathode, freezing water affects only the cathode reactive area.

(2) Other than the water carried away by the cathode gas, the water produced at the cathode freezes immediately at the reactive area, and the reactive area decreases with the increase in frozen water.

(3) The total pressure is constant.

(4) Water enters and leaves in the form of steam.

( 5 ) Voltage is constant over the area of the cell due to the high electronic conductivity of the current collectors.

(6) The M \& E assembly is thin and the electrochemical reactions are considered one dimensional.

Equation (6) describes the relation between the current distribution in the cathode, $I_{y}$, and the reactive area, $A_{v}$, the catalyst surface area per unit volume of catalyst layer,
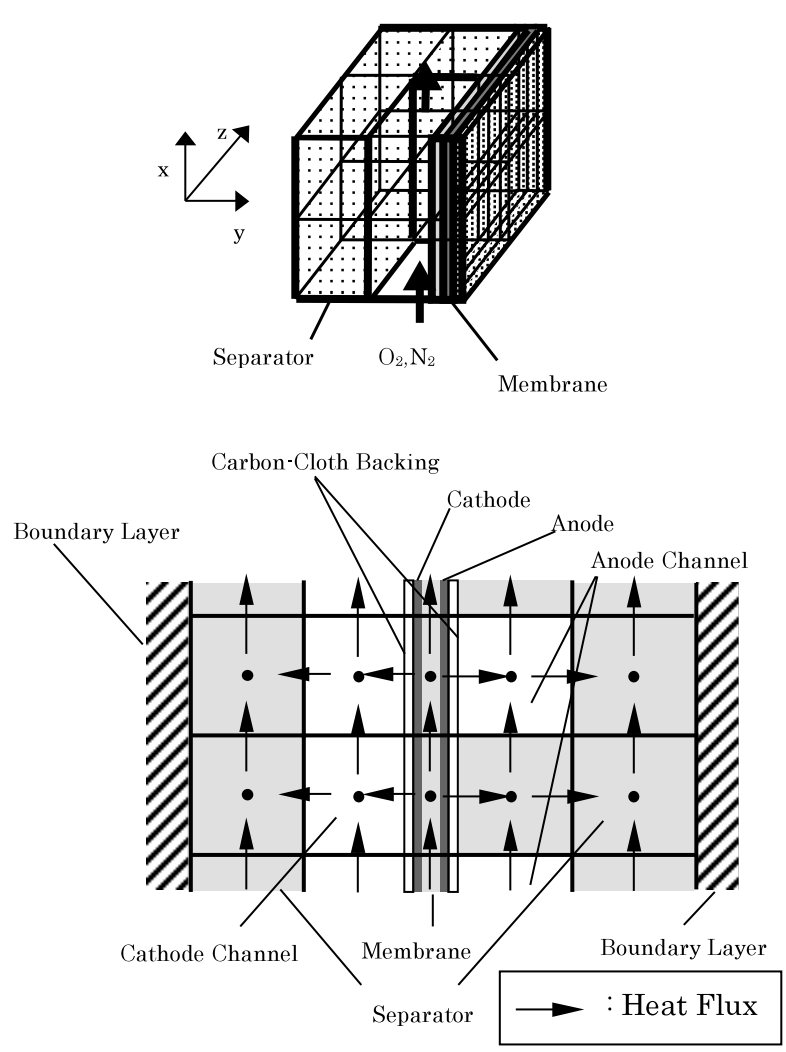

Fig. 4 Models for the simulation of heat

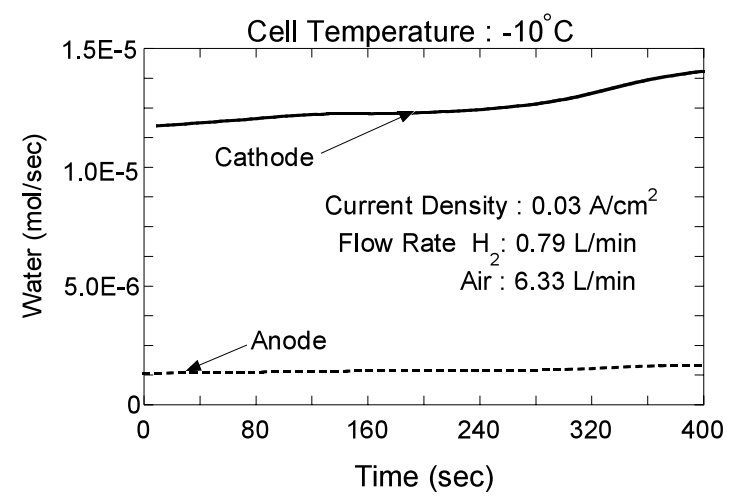

Fig. 5 Amount of water at anode and cathode

and here $\eta$ is the cathode overpotential, $\alpha_{c}$ is the cathodic transfer coefficient, and $i_{0}^{+}$is the exchange current density. The calculations use the input parameter shown in Table 1. The solution for the current distribution is obtained by integrating Eq. (6). The four unknown factors, $\eta, I_{y}, N_{\mathrm{O}_{2}}$ and $\left(C_{\mathrm{O}_{2}}\right)_{g}$ are described by Eqs. (6) to (9).

$$
\begin{aligned}
& \frac{d I_{y}}{d y}=A_{v} i_{0}^{+}\left[\exp \left(\frac{\alpha_{c} F \eta}{R T_{s}}\right)-\exp \left(\frac{-\alpha_{a} F \eta}{R T_{s}}\right)\right] \\
& \frac{d \eta}{d y}=\frac{I_{y}}{\sigma_{\text {cat }}} \\
& \frac{d\left(N_{\mathrm{O}_{2}}\right)}{d y}=\frac{-1}{4 F} \frac{d I_{y}}{d y}
\end{aligned}
$$




$$
\frac{d\left(C_{\mathrm{O}_{2}}\right)_{g}}{d y}=-\frac{N_{\mathrm{O}_{2}}}{D_{\mathrm{O}_{2}}}
$$

The reactive area, $A_{v}$, is assumed to decrease in proportion to the amount of frozen water at the next time step as shown by Eq. (10).

$$
A_{v}^{t+1}=A_{v}^{t}-k \cdot W_{c f}^{t}
$$

The $W_{c f}^{t}$ term is the amount of frozen water at the cathode layer in a time step, as shown by Eq. (11) which is calculated as the difference between the amount of water produced, $W_{c}^{t}$, and the amount which the cathode gas carries away, $W_{c g}^{t} ; W_{c g}^{t}$ is calculated considering the cathode gas humidity where $W_{c g}^{t}$ is evaporated to the cathode gas until the humidity becomes saturated. The water produced at the cathode, $W_{c}^{t}$, is calculated due to the Eq. (4)

$$
W_{c f}^{t}=W_{c}^{t}-W_{c g}^{t}
$$

The $k$ term in Eq. (10) is a proportionality constant, which is determined by fitting experimental currentpotential curves. It expresses the reactive area covered with frozen water per unit mole and is affected by the temperature and current density. The mean current density, flow rate, and inlet temperature of hydrogen, oxygen, and nitrogen are given; the gas pressure is atmospheric; the cell voltages, current densities, and temperature of the polymer electrolyte, separators, and gases are calculated over all areas of the fuel cell. The reactive area was divided into $20 \times 20$ elements in the $x$ and $z$ directions and 5 in the $y$ direction. The calculation time step was $0.1 \mathrm{sec}$. In the simulation two cases were calculated. One is a single cell simulating the experimental results, and the other an adiabatic cell assuming a stack with many cells. The method of the calculation is shown in the Refs. (2), (5) and (6).

Table 1 Input parameters

\begin{tabular}{|l|c|}
\hline Gas Flow Channel Width $(w)$ & $0.1 \mathrm{~cm}$ \\
\hline Gas Flow Channel Height $(d)$ & $0.1 \mathrm{~cm}$ \\
\hline Gas Flow Channel Length $(L)$ & $10.2 \mathrm{~cm}$ \\
\hline Number of the Channels $(N)$ & 51 \\
\hline Backing Layer Thickness $\left(t_{b}\right)$ & $4.7 \times 10^{-2} \mathrm{~cm}$ \\
\hline Catalyst Layer Thickness $\left(t_{d}\right)$ & $1.6 \times 10^{-3} \mathrm{~cm}$ \\
\hline Membrane thickness $\left(t_{m}\right)$ & $0.3 \times 10^{-2} \mathrm{~cm}$ \\
\hline Membrane Dry Density $\left(\rho_{m, d r y}\right)$ & $2.0 \mathrm{~g} / \mathrm{cm}^{3}$ \\
\hline Membrane Dry Equivalent Weight $\left(M_{m, d r y}\right)$ & $1100 \mathrm{~g} / \mathrm{mol}^{\prime}$ \\
\hline Conductivity of Backing Layer $\left(\sigma_{d}\right)$ & $18.5 \mathrm{~S} / \mathrm{cm}^{\prime}$ \\
\hline Resistivity of Carbon Separator $\left(\rho_{s}\right)$ & $1.375 \Omega \mathrm{m}^{2}$ \\
\hline Contact Resistance $\left(R_{\text {contact }}\right)$ & $1.04 \times 10^{-2} \Omega \mathrm{cm}^{2}$ \\
\hline Anodic Transfer Coefficient $\left(\alpha_{a}\right)$ & 0.54 \\
\hline Porosity in Gas Diffusion Backing $(\varepsilon)$ & 0.4 \\
\hline Cathodic Transfer Coefficient Parameter $\left(C_{d}\right)$ & 0.5 \\
\hline Initial Reactive Area $\left(A_{v}\right)$ & $1.4 \times 10^{4} \mathrm{~cm}^{2} / \mathrm{cm}^{3}$ \\
\hline
\end{tabular}

\section{Experimental Results}

The experimental results indicated in Figs. 6 - 8 were measured at the atmospheric pressure. Figure 6 shows the experimental results at $-25^{\circ} \mathrm{C}$. The initial voltage is $0.621 \mathrm{~V}$ at a current density $0.005 \mathrm{~A} / \mathrm{cm}^{2}$, and $0.755 \mathrm{~V}$ at $0.001 \mathrm{~A} / \mathrm{cm}^{2}$. The voltages decrease steadily and become less than $0.1 \mathrm{~V}$ in 18 and 950 seconds respectively. It is suggested that the reaction resistance increases by freezing of the produced water at the reactive area. At higher current densities, the amount of produced water increases, so the decrease in the cell voltage is steeper because of increases in the amount of produced water. Figure 7 shows experimental results at $-20^{\circ} \mathrm{C}$. The initial voltage is $0.825 \mathrm{~V}$ at current density $0.003 \mathrm{~A} / \mathrm{cm}^{2}$, $0.807 \mathrm{~V}$ at $0.01 \mathrm{~A} / \mathrm{cm}^{2}$, and 0.718 at $0.03 \mathrm{~A} / \mathrm{cm}^{2}$. The voltage stabilizes at the $0.003 \mathrm{~A} / \mathrm{cm}^{2}$ current density. At higher current densities, the voltage decreases quickly like in the experiment at $-25^{\circ} \mathrm{C}$ and it becomes less than $0.1 \mathrm{~V}$ in 800 seconds at $0.01 \mathrm{~A} / \mathrm{cm}^{2}$ and in 530 seconds at $0.03 \mathrm{~A} / \mathrm{cm}^{2}$. Figure 8 shows the experimental results at $-10^{\circ} \mathrm{C}$. The initial cell voltage is $0.770 \mathrm{~V}$ at current density $0.01 \mathrm{~A} / \mathrm{cm}^{2}, 0.717 \mathrm{~V}$ at $0.015 \mathrm{~A} / \mathrm{cm}^{2}, 0.690 \mathrm{~V}$ at $0.03 \mathrm{~A} / \mathrm{cm}^{2}$, and $0.695 \mathrm{~V}$ at $0.05 \mathrm{~A} / \mathrm{cm}^{2}$. The cell voltage stabilizes at $0.01 \mathrm{~A} / \mathrm{cm}^{2}$. Like in the experiments at -25 and $-20^{\circ} \mathrm{C}$, the voltages at $-10^{\circ} \mathrm{C}$ also keep de-

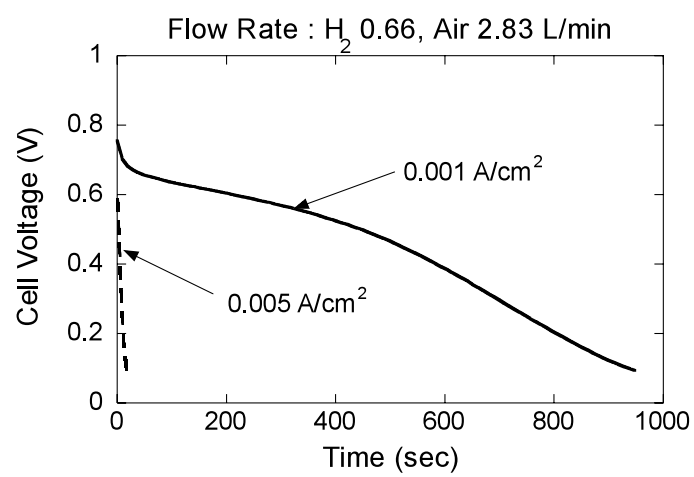

Fig. 6 Experimental results with start-up of the fuel cell at a cell temperature of $-25^{\circ} \mathrm{C}$

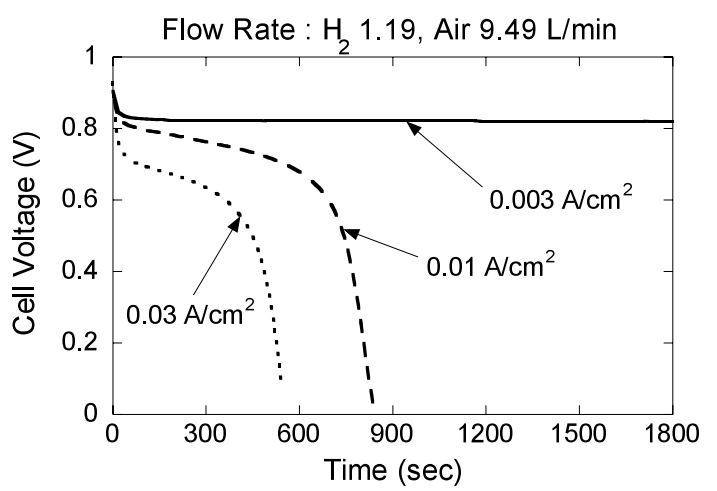

Fig. 7 Experimental results with start-up of the fuel cell at $-20^{\circ} \mathrm{C}$ 
creasing and become less than $0.1 \mathrm{~V}$ in 1560 seconds at $0.015 \mathrm{~A} / \mathrm{cm}^{2}$, in 730 seconds at $0.03 \mathrm{~A} / \mathrm{cm}^{2}$, and in 380 seconds at $0.05 \mathrm{~A} / \mathrm{cm}^{2}$.

At $-20^{\circ} \mathrm{C}$, the voltage stabilized at a hydrogen flow rate of $1.19 \mathrm{~L} / \mathrm{min}$, air flow rate $9.49 \mathrm{~L} / \mathrm{min}$, and the current density $0.003 \mathrm{~A} / \mathrm{cm}^{2}$; and at $-10^{\circ} \mathrm{C}$ it stabilized with the hydrogen flow rate $0.79 \mathrm{~L} / \mathrm{min}$, air flow rate $6.33 \mathrm{~L} / \mathrm{min}$, and current density $0.01 \mathrm{~A} / \mathrm{cm}^{2}$. To maintain the performance at temperatures below freezing, it appears necessary that the water produced and removed is in balance to stabilize the voltage. It is estimated that there is no freezing when the amount of produced water, $W_{c}$, is equal to the amount of water which the cathode gas carries away, $W_{c g}$, as shown by Eq. (12).

$$
W_{c}=W_{c g}
$$

The cause of the voltage drop at higher current densities is that frozen water covers more of the reactive area, blocking the absorption and diffusion of gas molecules at temperatures below freezing because the amount of produced water increases with the current density.

Figure 9 indicates the start-up characteristics of a fuel cell at the temperature of $-10^{\circ} \mathrm{C}$ and the pressures of $1,1.5$ and $2 \mathrm{~atm}$. The higher the pressure, the steeper the voltage drop because produced water is hold on the reactive area

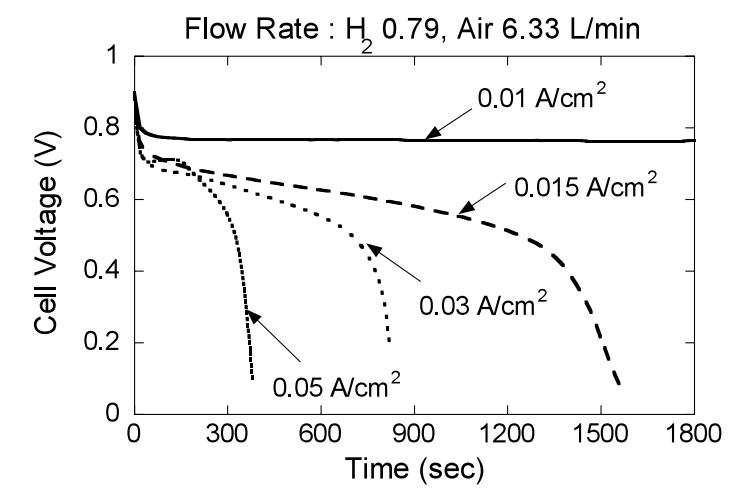

Fig. 8 Experimental results with start-up of the fuel cell at $-10^{\circ} \mathrm{C}$

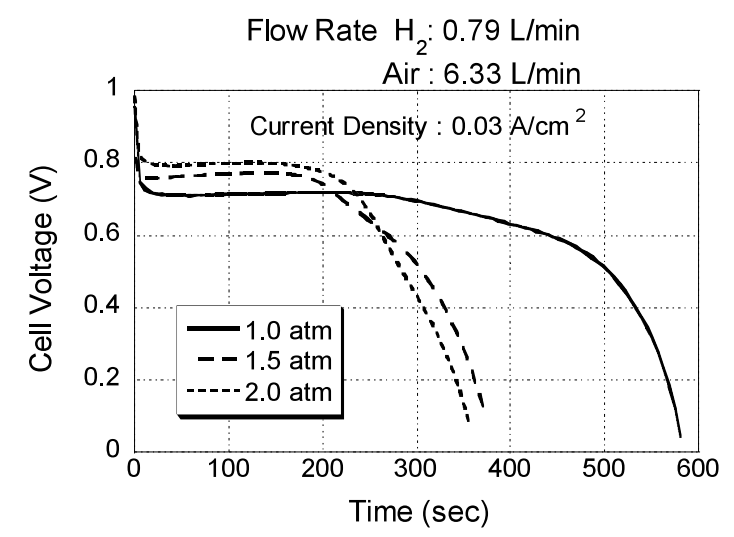

Fig. 9 Start-up characteristics of a fuel cell at $-10^{\circ} \mathrm{C}$ and various pressures more than at the atmospheric pressure.

\section{Modeling Analysis}

The curves in the Fig. 10 shows simulated results, while the dotes represent the experimental results. The solid line represents the simulated results at $-10^{\circ} \mathrm{C}$ and the broken line the results at $40^{\circ} \mathrm{C}$. The temperature of the inlet gases is equal to the initial cell temperature. Humidgases were used in the experiment at $40^{\circ} \mathrm{C}$. The utilization of the anode and cathode gases, $\eta_{h}$ and $o$ defined, as by Eq. (13), is 0.8 and 0.5 respectively.

$$
\eta_{h} \text { and } o=\frac{\text { stoichiometric gas flow rate }}{\text { supplied gas flow rate }}
$$

The results at $-10^{\circ} \mathrm{C}$ in the graph are obtained neglecting the freezing of produced water. Figure 10 shows that the experimental results are simulated well by the model.

Figure 11 shows a simulation considering water freezing. The dots in the graph indicate the experimental results and the curve shows the simulated results. The experimentally established drop in the cell voltage is reproduced in the simulation. Figures 12 and 13 show the simulated results when changing the current density and the cell temperature with the results in Fig. 11. Figure 12 shows that the $k$ value decreases at higher current densities, where the amount of produced water increases with the current density. Figure 13 shows that the $k$ value de-

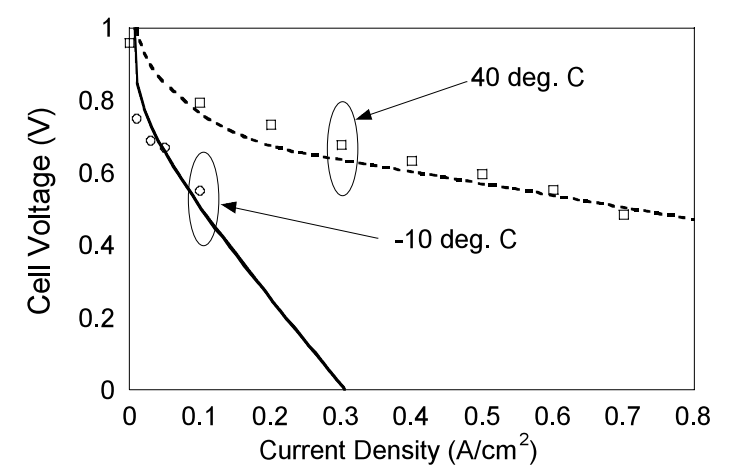

Fig. 10 Experimental results and modeling analysis of $V-I$ characteristics

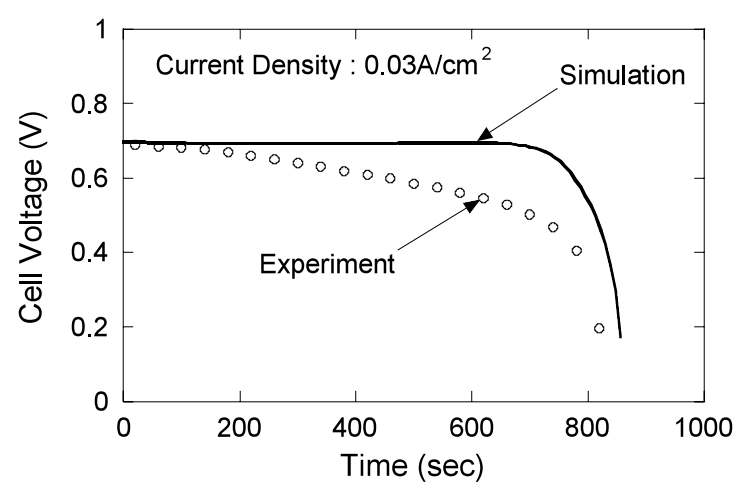

Fig. 11 Experimental results and modeling analysis at $-10^{\circ} \mathrm{C}$ 


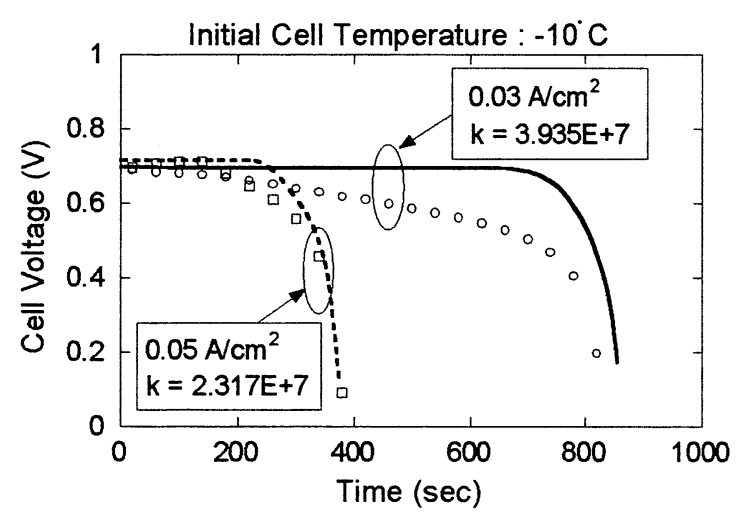

Fig. 12 Comparison of the $k$ value at the current densities $0.03 \mathrm{~A} / \mathrm{cm}^{2}$ and $0.05 \mathrm{~A} / \mathrm{cm}^{2}$ at $-10^{\circ} \mathrm{C}$

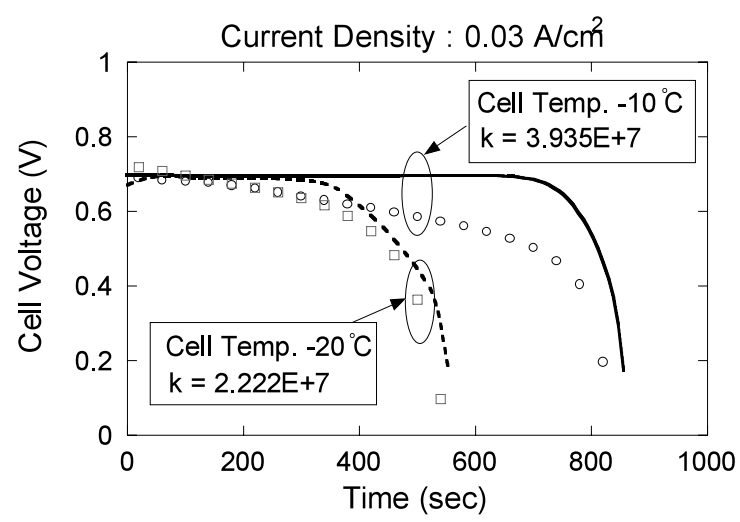

Fig. 13 Comparison of the $k$ value at the cell temperatures $-10^{\circ} \mathrm{C}$ and $-20^{\circ} \mathrm{C}$ at $0.03 \mathrm{~A} / \mathrm{cm}^{2}$

creases at lower cell temperatures, where the amount of frozen water increases because the water, which the cathode gas carries away decreases at the lower cell temperature.

Figure 14 shows the changes in reactive area in the fuel cell simulated by the model. The values in the distribution diagrams were made dimensionless by the initial value of the reactive area per unit volume. These diagrams were calculated at 0,780 and $856 \mathrm{sec}$, and clearly indicate that the reactive area becomes smaller due to the freezing, and that freezing started from the downstream side of the cathode. The steam partial pressure of the cathode gas is higher downstream in the cathode channels and the water left there freezes at the reactive area.

These results appear to show that it is necessary to heat the cell to above the freezing point to be able to start the fuel cell at temperatures below freezing. Figure 15 shows simulated results assuming heating of the gas by a catalyst combustion vessel. The current density and gas flow rate satisfy Eq. (12) and the initial cell temperature is $-20^{\circ} \mathrm{C}$. The solid lines are the cell voltage and the broken lines are the cell temperature. The gas was supplied at three temperatures, $-20^{\circ} \mathrm{C}$ (thinnest lines), $20^{\circ} \mathrm{C}$ (intermediate lines) and at $40^{\circ} \mathrm{C}$ (thickest lines). Considering

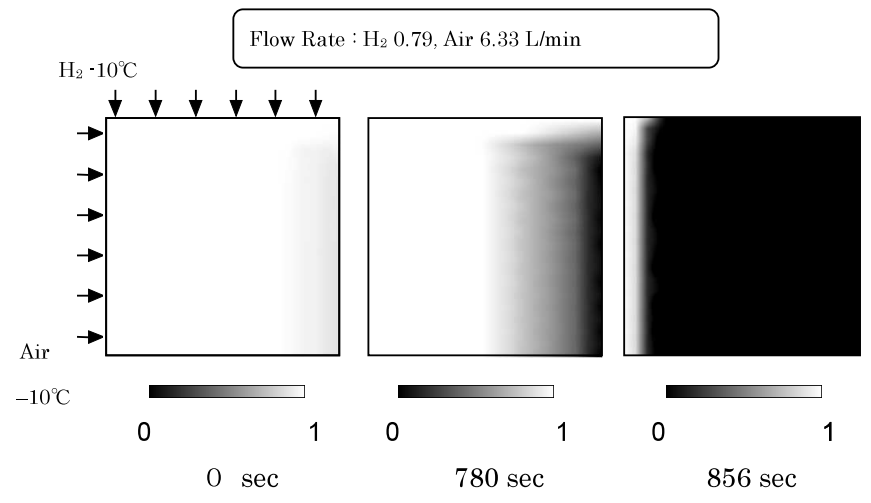

(Current Density:0.03A/cm2, Initial Cell Temperature: $-10^{\circ} \mathrm{C}$ )

Fig. 14 Reacting areas in the membrane at cell temperature $-10^{\circ} \mathrm{C}$

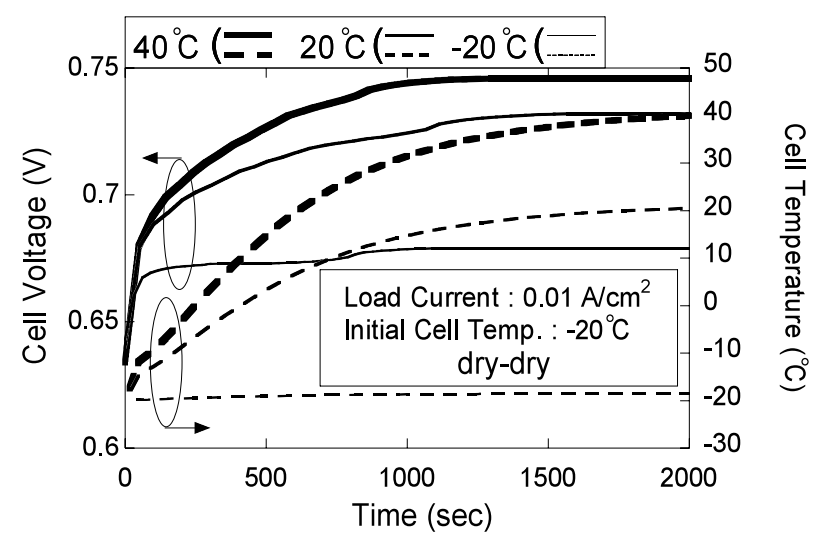

Fig. 15 Cell temperatures with heating (solid lines) and without heating (broken lines)

the stack condition in this analysis the boundary condition is assumed to be adiabatic. With a $-20^{\circ} \mathrm{C}$ gas supply, the total heat generated by the reaction, the energy loss by the overpotential and the Joule heat by the internal resistance in the cell, and the heat which the gases carry away balance at $-18.5^{\circ} \mathrm{C}$ where the cell temperature becomes steady. At the $20^{\circ} \mathrm{C}$ and $40^{\circ} \mathrm{C}$ gas supply temperatures, the cell temperature rises to the gas supply temperature, and the cell voltage increases with the rise in the cell temperature because the reaction rate increases. As a result, self-starting of a fuel cell at $-20^{\circ} \mathrm{C}$ appears difficult, making it necessary to supply heated gases for starting at low temperatures.

The working temperature of the fuel cell was simulated with initial cell temperatures of $-20,-10,-5,0$, and $5^{\circ} \mathrm{C}$. The gas flow rates and current densities were set to maintain a balance between the amount of water produced and the amount carried away by the cathode gas ${ }^{(4)}$. The period of operation was 30 minutes, and in this analysis the boundary condition is adiabatic as in Fig. 15. Figure 16 shows that the working temperature increases and exceeds $0^{\circ} \mathrm{C}$ in $70 \mathrm{sec}$ with the $-5^{\circ} \mathrm{C}$ starting temperature. As a result self-starting of fuel cells appears practical at 


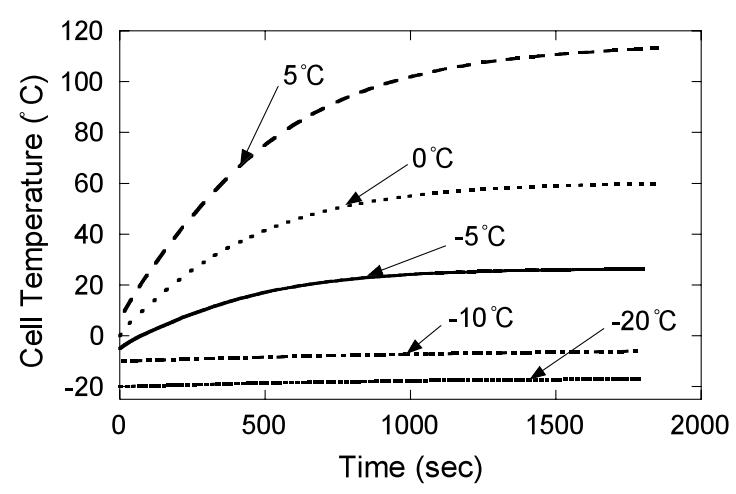

Fig. 16 Rise in temperature at various initial temperatures

temperatures above $-5^{\circ} \mathrm{C}$, but when the initial cell temperature is -20 or $-10^{\circ} \mathrm{C}$, the gases carry away most of the heat of the electro-chemical reaction and self-starting appears difficult. Here it would be necessary to supply heat for the cell to operate.

\section{Conclusions}

The characteristics of a PEFC at temperatures below freezing were studied by experiments and by the modeling analysis. The conclusions of the study are as follows:

(1) The performance of the fuel cell was evaluated at temperatures below freezing, and the cell potential decreases quickly at higher current densities and pressures, and lower cell temperatures.

( 2 ) The performance was successfully simulated assuming that the reactive area decreases in proportion to the amount of produced water, and the experimental results were simulated well.
(3) The simulation indicated that freezing started from the downstream side of the cathode. The steam partial pressure of the cathode gas is higher downstream in the cathode channels, and the water left there freezes in the reactive area.

(4) The modeling analysis estimated that selfstarting is possible when the initial fuel cell temperature is about $-5^{\circ} \mathrm{C}$. When the initial fuel cell temperature is below $-5^{\circ} \mathrm{C}$, the gases carry away most of the heat generated by the electro-chemical reaction, and self-starting becomes difficult. To operate the cell at low temperatures it is necessary to heat the cell.

\section{References}

( 1 ) Yoshikawa, H., Hishinuma, Y. and Chikahisa, T., Proc. of JSME Annual Meeting (1), (in Japanese), (2000), pp.687-688.

(2) Yoshikawa, H., Hishinuma, Y. and Chikahisa, T., Trans. of JSME (B), (in Japanese), Vol.66, No.652 (2000), pp.3218-3225.

( 3 ) Yoshikawa, H., Hishinuma, Y. and Chikahisa, T., Heat Transfer-Asian Research, Vol.31, No.6 (2002), pp.421-429.

( 4 ) Takagi, Y., Hishinuma, Y. and Chikahisa, T., Proc. of 40th JSME in Hokkaido Branch, (in Japanese), No.002-1 (2000), pp.156-157.

( 5 ) Hishinuma, Y., Chikahisa, T., Yoshikawa, H. and Kamo, T., Proc. of the 5th ASME/JSME Joint Thermal Engneering, (1999), AJTE99-6343.

( 6 ) Kagami, F., Ogawa, T., Hishinuma, Y. and Chikahisa, T., Thermal Science and Engineering, Vol.10, No.3 (2002) pp.25-33. 